\title{
Endovascular treatment of a large ruptured middle cerebral artery bifurcation aneurysm in a 5-week-old infant: case report
}

\author{
Kristopher A. Lyon, MD, ${ }^{1}$ Eliel N. Arrey, MD, ${ }^{2}$ Ali S. Haider, BS, ${ }^{1}$ Dhruve S. Jeevan, MD, and \\ Ethan A. Benardete, MD, PhD'1
}

1Department of Neurosurgery, Scott and White Medical Center, Texas A\&M University Health Science Center College of Medicine, Temple; and ${ }^{2}$ University of Texas Health Science Center, McGovern Medical School, Houston, Texas

\begin{abstract}
Ruptured intracranial aneurysms are extremely rare in infants. The optimal treatment strategy is not well established. Both microsurgical and endovascular techniques and strategies have been tried, and in the literature there is a significant variability in outcome. The authors report the presentation and successful endovascular treatment of a large, ruptured, middle cerebral artery bifurcation aneurysm in a 5-week-old girl, one of only a few reported in the literature. Clinical and radiological findings at follow-up are also presented. The authors then review the literature on aneurysmal subarachnoid hemorrhage in infants, with particular regard to outcome after either endovascular or open surgical management. They also provide recommendations for follow-up in pediatric patients whose intracranial aneurysms have been treated with coil embolization.
\end{abstract}

https://thejns.org/doi/abs/10.3171/2017.5.PEDS17116

KEY WORDS neonate; intracranial aneurysm; endovascular; coil embolization; subarachnoid hemorrhage; vascular disorders

I NTRACRANIAL aneurysms in the pediatric population are rare, with an approximate incidence of $0.5 \%-4.6 \%$ of all cerebral aneurysms. 2,4,6,12,20,28 Today, the number of reported cases of infantile intracranial aneurysms (ruptured and unruptured) numbers fewer than 150, with the number of intracranial aneurysms reported in neonates totaling fewer than $30 .^{2,4}$ Until recently, the most common surgical treatment of these patients had been with open microsurgery, typically clipping. $1,4-7,9,11-16,20,26-29,33,34,36,39,40$ In the last few years, endovascular approaches to ruptured aneurysms in this age group have emerged as effective. ${ }^{5,7}$, 12,26,28,29 This report illustrates successful endovascular treatment of a spontaneously ruptured intracranial saccular aneurysm in a 5-week-old infant. To our knowledge, this patient represents the eighth case of a ruptured saccular aneurysm in a child less than 3 months old treated with coil embolization. A literature review is provided to compare the treatment and outcomes of ruptured intracra- nial saccular aneurysms in infants less than 3 months old, in terms of endovascular and microsurgical techniques.

\section{Case Report}

History and Examination

A healthy 5-week-old African American girl born at 40 weeks by uncomplicated cesarean delivery was breastfeeding when she suddenly made a loud squeal, became limp, and then started shaking. There was no history of trauma. The mother (gravida 2, para 2) had no significant medical history. Following this episode, the patient remained unarousable, and on arrival at an outside hospital, she was bradycardic, apneic, and required intubation for airway protection. An emergency noncontrast head CT scan was obtained, which demonstrated acute subarachnoid hemorrhage (SAH) within the basal cisterns and right sylvian fissure, with associated midline shift (Fig. 1A and B). The

ABBREVIATIONS ACA = anterior cerebral artery; $\mathrm{AP}=$ anteroposterior; $I C A=$ internal carotid artery; $M C A=$ middle cerebral artery; $M R A=M R$ angiography; PICA = posterior inferior cerebellar artery; $\mathrm{SAH}=$ subarachnoid hemorrhage.

SUBMITTED March 5, 2017. ACCEPTED May 12, 2017.

INCLUDE WHEN CITING Published online August 4, 2017; DOI: 10.3171/2017.5.PEDS17116. 

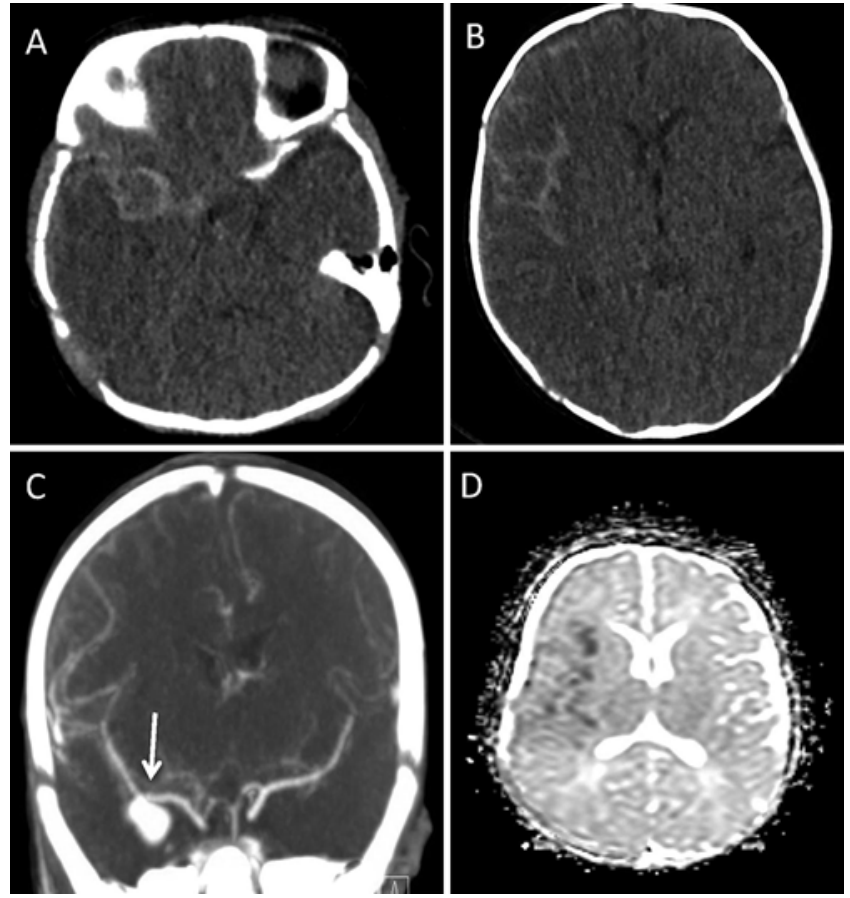

FIG. 1. Neuroimaging studies obtained at initial evaluation. A and B: Noncontrast axial CT scans showing blood within the right sylvian fissure and a "halo" around the large MCA aneurysm. C: Coronal CT angiogram of the head showing a large saccular aneurysm (arrow) at the right MCA bifurcation measuring $13 \mathrm{~mm}$ in maximum dimension. D: Axial MRI study obtained on the day of admission showing apparent diffusion coefficient map with evidence of ischemia in opercular cortex and insula. Diffusion-weighted imaging confirmed these findings (not shown).

infant was transferred on an emergency basis to our institution for a higher level of care.

On arrival, MRI and MR angiography (MRA) were obtained to evaluate for an aneurysmal source of the intracranial hemorrhage. A CT angiography study was also done to confirm the presence of a large saccular aneurysm. Both modalities revealed a middle cerebral artery (MCA) bifurcation aneurysm measuring $13 \mathrm{~mm}$ in maximum diameter (Fig. 1C). Pediatric and endovascular neurosurgery consults were obtained. After a management discussion, we proposed to take the patient to the angiography suite and attempt endovascular embolization.

\section{Operation}

The procedure was performed by the senior author (E.A.B.) after induction of general anesthesia. No neurophysiological monitoring was used. Access was obtained at the right common femoral artery with a 21 -gauge micropuncture needle. Using a Cope wire, a 4-Fr short sheath was exchanged for the needle. A 0.035 -in starter wire was then placed through the sheath into the descending aorta. The short sheath was then exchanged for a $65-\mathrm{cm} 4-\mathrm{Fr}$ multipurpose tipped Glidecath catheter (Terumo) connected to continuous heparinized flush (4000 U/L) kept at a low rate. A bolus of heparin was not given. Activated clotting times were not monitored. The catheter was then manipulated over the aortic arch over an angled 0.035-in Glidewire (Terumo). The catheter was advanced over the wire into the right common carotid artery. Under roadmap views, the catheter was further advanced into the distal right extracranial internal carotid artery (ICA).

Catheter angiography was used to confirm the anatomical location and dimension of the aneurysm (Fig. 2A). An Excelsior SL-10 microcatheter (Stryker Neurovascular) was advanced into the fundus of the aneurysm under high-magnification working views (Fig. 2B). During the catheterization phase of the procedure, attention was paid to minimizing the total volume $(10 \mathrm{ml})$ of contrast agent used (Omnipaque 300; GE Healthcare). We used plain platinum coils for the embolization phase of the procedure (Target 360; Stryker Neurovascular). We took care to avoid prolapse of the coil loops into the neck of the aneurysm, which might cause occlusion of one of the $\mathrm{M}_{2}$ trunks of the MCA. The first coil placed into the aneurysm fundus was an $8-\mathrm{mm} \times 20-\mathrm{cm}$, complex-shaped coil. Twelve additional coils of gradually decreasing diameter were placed until the aneurysm was excluded from the circulation (Fig. 2C). Control angiography demonstrated exclusion of the aneurysm from the circulation, except for a small area near the neck measuring approximately $2 \mathrm{~mm} \times 1 \mathrm{~mm} \times 1 \mathrm{~mm}$ (Raymond-Roy Class 2). Patency of all parent vessels was demonstrated on control angiography (Fig. 2D). The procedure was completed and the catheters were removed after a total of 37 minutes of fluoroscopy (both planes). Gentle compression completed hemostasis of the puncture site. Postoperatively, the patient returned to the ICU with intubation. She was extubated shortly thereafter, and she began bottle-feeding without difficulty.

\section{Postoperative Course}

The patient was observed in the ICU for 10 days. Normotension and normovolemia were maintained. Daily transcranial Doppler ultrasound and MRA sequences of the brain were used to monitor for vasospasm. This testing indicated only mild vasospasm in the right MCA, which resolved during her hospitalization. While in the hospital, the patient had intermittent left upper-extremity shaking. An electroencephalogram performed at the time demonstrated spikes and waves in the right central region, consistent with the area of restricted diffusion seen in the right MCA distribution on MRI obtained prior to intervention (Fig. 1D). Fourteen days after the procedure, she was discharged home with equal strength, tone, and movement in bilateral upper and lower extremities. Antiepileptic medications were continued for her occasional seizure activity. In her 6-month follow-up visit, she was making appropriate developmental milestones but still had rare flexion and extension spasms while on anticonvulsant medication. Repeat MRA and catheter angiography at her 7-month follow-up showed complete occlusion of a previously embolized large right MCA aneurysm (Raymond-Roy Class 1) with preservation of the parent vessels (Fig. $3 \mathrm{~A}$ and $\mathrm{B}$ ). An MRI study of the brain showed volume loss in the right hemisphere, probably secondary to the prior injury from the SAH (Fig. 3C and D). At the 10-month follow-up visit, she continued to do well and had met all developmental milestones. Although she was still receiving antiepileptic drugs, her seizure activity had ceased. 


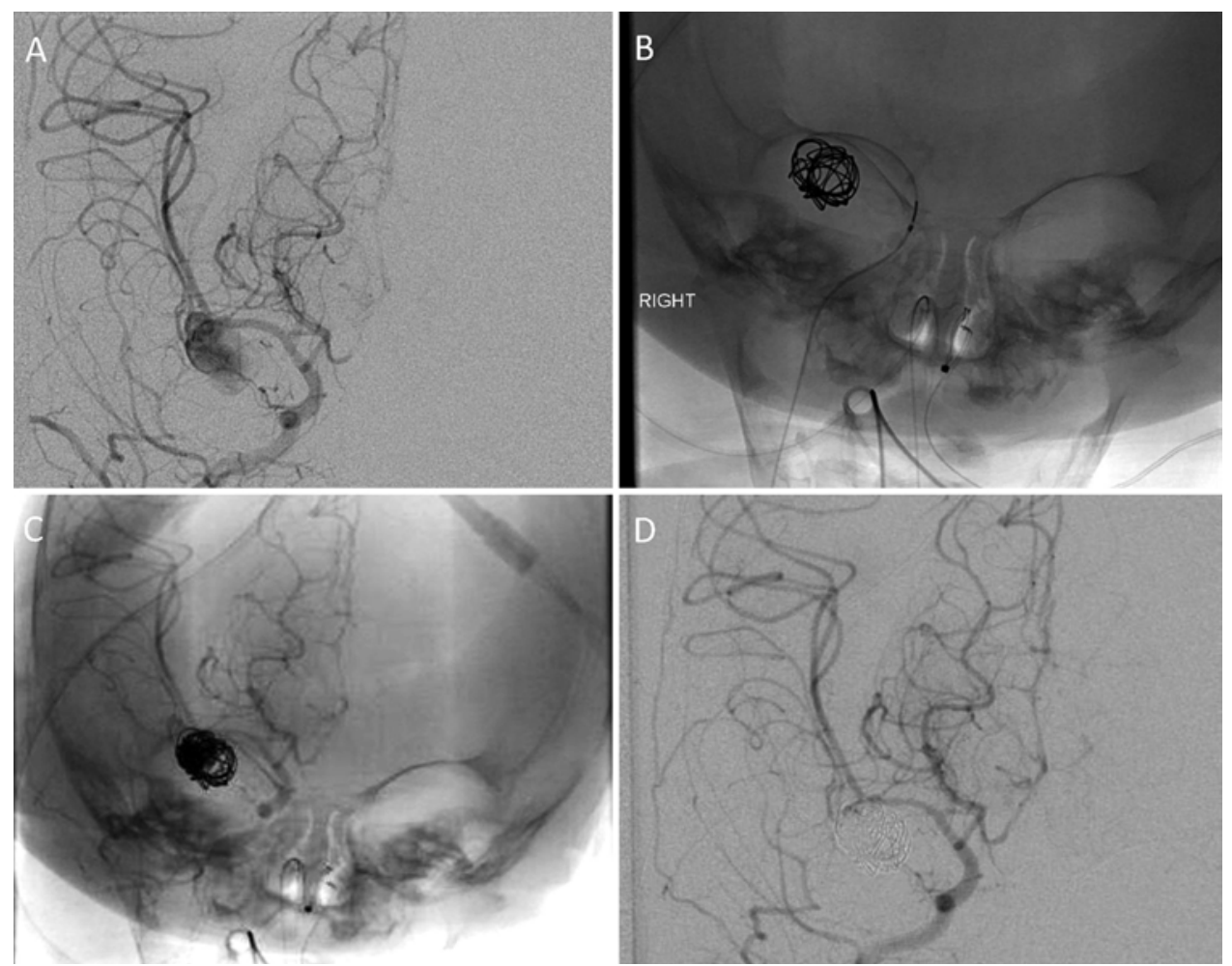

FIG. 2. Neuroimaging studies obtained at catheter intervention. A: Anteroposterior (AP) angiographic image of the right ICA injection showing a large, relatively slow-filling aneurysm of the right MCA bifurcation. B: Coil embolization of this large MCA bifurcation aneurysm was performed using native and roadmap views, holding contrast administration to a minimum. C and D: Postembolization angiograms (AP view) showing no filling of aneurysm and patency of the right MCA trunk and branches.

\section{Discussion \\ Etiology of Lesions}

Saccular aneurysms in infants are extremely rare, so much so that Stehbens in the classic work published in 1972, Pathology of the Cerebral Blood Vessels, doubted their existence. ${ }^{31}$ Large autopsy studies done at that time had failed to find a single one, leading the author to suggest that intracranial aneurysms must be an acquired abnormality. Nevertheless, over the ensuing years, case reports such as ours have demonstrated unquestionably the existence of saccular aneurysms in the neonate and young infant. Nevertheless, the problem of their etiology remains unanswered because the literature remains heterogeneous with respect to aneurysm type, predisposing factors, and extent of follow-up.

We focused our review on ruptured saccular aneurysms in infants less than 3 months old. We found 26 surgically treated cases clearly documented in the literature, 8 of which (including ours) were treated endovascularly (Table 1). In this group, the MCA (18 of 26) is the most common location, although not all of these aneurysms occurred at the bifurcation. For example, the report by Rana et al. from 2007 describes 2 cases of distal saccular MCA aneurysms treated endovascularly. ${ }^{26}$ The other aneurysm locations found in our review, such as cavernous ICA, anterior cerebral artery (ACA), or posterior inferior cerebellar artery (PICA) are minimally represented. The embryological development of intracranial vessels may explain why the majority of infants with aneurysms have them near the MCA, because it and the ICA develop earlier and receive more blood flow than other vessels in the cerebrum. ${ }^{40}$ In 1978, Grode et al. performed pathological examinations on the walls of 2 neonatal aneurysms; both showed findings similar to adult aneurysms, with disruption of the arterial layers and thinning of the wall. ${ }^{9}$

Although connective tissue disorders (such as EhlersDanlos syndrome or Marfan syndrome) and other hereditary factors (sickle cell anemia, polycystic kidney disease, neurofibromatosis Type 1) are frequently mentioned as predisposing causes in the pediatric aneurysm population, none of the patients in the literature on treated neonatal aneurysmal SAH had one of these conditions. ${ }^{3}$ Many authors have speculated that birth-related or perinatal trauma (accidental or deliberate) may also cause aneurysms or precipitate a rupture. ${ }^{22}$ However, in most cases in our review, no clear traumatic event had occurred.

\section{Patient Presentation}

Infants with aneurysmal SAH present in different ways, but abrupt neurological decline and seizures are common. ${ }^{34}$ The most common presentation of SAH is acute loss of consciousness, as seen in our patient. ${ }^{37}$ Subarachnoid hemorrhage is easily detected with CT imaging of the head. Because this directs a high level of radiation to the developing brain, Tekkök and Ventureyra (1997) argue that transfontanelle cranial ultrasonography should be the 

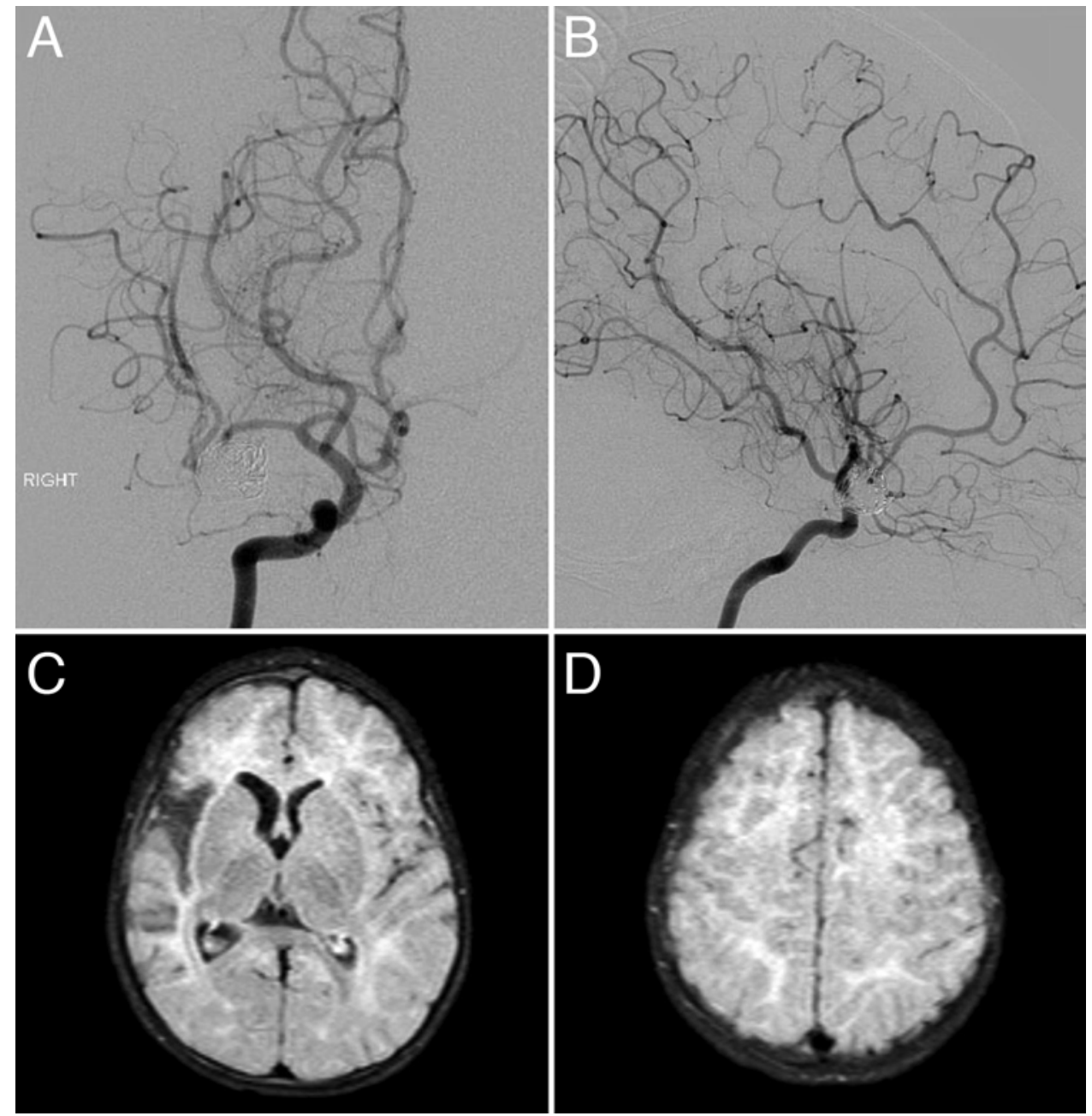

FIG. 3. Neuroimaging studies obtained at 6-month follow-up. A and B: Angiographic images (AP and lateral) of the right ICA injection showing stable occlusion of the large right MCA aneurysm without evidence of recurrence and patent branches. $\mathbf{C}$ and D: Axial FLAIR MR images showing loss of volume in the right opercular and insular cortex corresponding to an area of early ischemia and otherwise normal-appearing cortical convexities.

first investigation in neonates; it demonstrates the location and size of the hemorrhage, the degree of hydrocephalus, and may show the aneurysm itself. ${ }^{32}$ To confirm the findings on ultrasound or CT, an MR image or MR angiogram of the head should be ordered before a CT angiogram, to limit radiation exposure. ${ }^{39}$ Catheter angiography, typically via the transfemoral route, poses higher than average risks in the neonate and infant, and is probably best done as a confirmatory study or with an intent to treat endovascularly. Keeping the volume of contrast and the dose of iodine to a minimum is reasonable, given the risk of kidney injury.

\section{Treatment: Microsurgical Versus Endovascular}

Early series and case reports demonstrated that the mortality was high in cases of ruptured aneurysm occurring in infants in which patients were only supported medically. ${ }^{17-19,21,23,38}$ Both open surgical and endovascular treatment options have resulted in favorable outcomes. Van Raay et al. (2009) and Song et al. (2005) have even argued that surgery is better tolerated in infants than in adults. ${ }^{29,34}$ Table 1 summarizes the results of our review of infants less than 3 months old who were treated either by microsurgical clipping or endovascular intervention for a ruptured saccular intracranial aneurysm. The degree of impairment and the length of follow-up are variable. In both the clip ligation group and the endovascular group, some degree of neurological impairment is common during the follow-up period, when it is reported.

In most centers, endovascular approaches with detachable platinum coils are now viewed as a first-line treatment for adults with ruptured intracranial aneurysms, although aneurysms of the MCA are still often treated with open surgical clip ligation. In one review, the authors suggested that open surgical clipping may be favorable for children because of better durability; however, from our review it is not clear that either superior benefit or durability can be argued for one treatment modality or the other. ${ }^{12}$ Certainly, endovascular treatment has the advantage of less blood loss and less surgical trauma.

From the 8 cases in the literature (including this patient) illustrating coil embolization of ruptured aneurysms 
TABLE 1. Previous reports of aneurysmal rupture in the first 3 months of life from saccular aneurysms, with aneurysm location, treatment, and outcome

\begin{tabular}{|c|c|c|c|c|c|c|c|}
\hline Authors \& Year & Age, Sex & Presentation & $\begin{array}{l}\text { Aneurysm } \\
\text { Location }\end{array}$ & $\begin{array}{l}\text { Imaging } \\
\text { Findings }\end{array}$ & Treatment & $\begin{array}{l}\text { Outcome After } \\
\text { Intervention }\end{array}$ & Outpatient Follow-Up \\
\hline $\begin{array}{c}\text { Jones \& Shear- } \\
\text { burn, } 1961\end{array}$ & 28 days, $F$ & $\begin{array}{l}\text { Crying, seizures, eye } \\
\text { deviation }\end{array}$ & Rt MCA & $\mathrm{SAH}$ & Clipped & Good condition & Unknown \\
\hline $\begin{array}{l}\text { Vapalahti et al., } \\
\quad 1969\end{array}$ & 90 days, $F^{*}$ & $\begin{array}{l}\text { Vomiting, seizures, } \\
\text { hemiparesis }\end{array}$ & Rt MCA & SAH & Clipped & $\begin{array}{l}\text { Good condition; } \\
\text { resolved } \\
\text { hemiparesis }\end{array}$ & $\begin{array}{l}\text { Developmentally normal } \\
\text { at } 6 \text { wks }\end{array}$ \\
\hline $\begin{array}{l}\text { Grode et al., } \\
1978\end{array}$ & 8 days, $F$ & $\begin{array}{l}\text { Lethargy, vomiting, } \\
\text { seizures }\end{array}$ & Lt MCA & $\mathrm{SAH}$ & Clipped & $\begin{array}{l}\text { Intact neurologi- } \\
\text { cally }\end{array}$ & $\begin{array}{l}\text { Slight psychomotor } \\
\text { delay at } 3 \text { yrs }\end{array}$ \\
\hline $\begin{array}{l}\text { Hungerford et al., } \\
1981\end{array}$ & 28 days, $F$ & Crying, vomiting & Rt MCA & $\mathrm{SAH}, \mathrm{IPH}$ & Clipped & $\begin{array}{l}\text { Full recovery } \\
\text { after surgery }\end{array}$ & Unknown \\
\hline $\begin{array}{l}\text { Russegger \& } \\
\text { Grunert, } 1987\end{array}$ & 70 days, $\mathrm{F}^{*}$ & $\begin{array}{l}\text { Crying, vomiting, } \\
\text { seizures }\end{array}$ & Lt MCA & $\mathrm{SAH}, \mathrm{IPH}$ & Clipped & $\begin{array}{l}\text { Slight clumsi- } \\
\text { ness of rt arm }\end{array}$ & $\begin{array}{l}\text { Persistent rt arm clumsi- } \\
\text { ness at } 3 \text { mos }\end{array}$ \\
\hline $\begin{array}{l}\text { Thrush \& Ma- } \\
\text { rano, } 1988\end{array}$ & 28 days, $F$ & $\begin{array}{l}\text { Irritability, lethargy, } \\
\text { respiratory issues }\end{array}$ & Lt MCA & IPH & Clipped & $\begin{array}{l}\text { No neurological } \\
\text { deficits }\end{array}$ & Unknown \\
\hline $\begin{array}{l}\text { Hosotani et al., } \\
1995\end{array}$ & 24 days, $F$ & $\begin{array}{l}\text { Hydrocephalus, enlarging } \\
\text { head }\end{array}$ & Lt PICA & $\mathrm{SAH}$ & Clipped & $\begin{array}{l}\text { No neurological } \\
\text { deficits }\end{array}$ & Alive at $7 \mathrm{mos}$ \\
\hline $\begin{array}{l}\text { Allison et al., } \\
1998\end{array}$ & 30 days, $\mathrm{M}^{*}$ & Hydrocephalus & Lt MCA & SAH, IPH & $\begin{array}{l}\text { Open surgery, } \\
\text { unknown }\end{array}$ & $\begin{array}{l}\text { Alive, unknown } \\
\text { condition }\end{array}$ & Unknown \\
\hline $\begin{array}{l}\text { Jansen et al., } \\
2000\end{array}$ & 30 days, $F^{*}$ & $\begin{array}{l}\text { Irritability, vomiting, eye } \\
\text { deviation }\end{array}$ & Lt PICA & SAH, IPH & Clipped & $\begin{array}{l}\text { No neurological } \\
\text { deficits }\end{array}$ & Alive at $18 \mathrm{mos}$ \\
\hline $\begin{array}{l}\text { Kourtopoulos et } \\
\text { al., } 2000\end{array}$ & 13 days, $F$ & Failure to thrive & Lt MCA & IPH, IVH & Clipped & $\begin{array}{l}\text { No neurological } \\
\text { deficits }\end{array}$ & Alive at $1 \mathrm{yr}$ \\
\hline $\begin{array}{l}\text { Young \& Pat- } \\
\text { tisapu, } 2000\end{array}$ & 39 days, $M$ & $\begin{array}{l}\text { Somnolence, bulging } \\
\text { fontanelle }\end{array}$ & Lt MCA & SAH, IPH & $\begin{array}{l}\text { Bipolar co- } \\
\quad \text { agulation }\end{array}$ & $\begin{array}{l}\text { Rt hemiparesis, } \\
\text { dev delays, } \\
\text { seizures }\end{array}$ & Alive at $2 \mathrm{yrs}$ \\
\hline $\begin{array}{l}\text { Maroun et al., } \\
2003\end{array}$ & 3 days, $M$ & $\begin{array}{l}\text { Irritability, seizures, } \\
\text { hypertonia, dilated It } \\
\text { pupil }\end{array}$ & Lt MCA & $\mathrm{SAH}$ & Clipped & $\begin{array}{l}\text { Bilat CN III pa- } \\
\text { resis, spastic } \\
\text { tetraparesis }\end{array}$ & Dead at 4 yrs old \\
\hline Song et al., 2005 & 11 days, $F$ & $\begin{array}{l}\text { Irritability, seizures, } \\
\text { neglect, choreiod } \\
\text { movements, disconju- } \\
\text { gate gaze }\end{array}$ & $\begin{array}{l}\text { ACoA, bilat } \\
\text { ACA, It } \\
\text { ICA }\end{array}$ & IPH, IVH & Coiled & $\begin{array}{l}\text { Significant recov- } \\
\text { ery from preop } \\
\text { presentation }\end{array}$ & $\begin{array}{l}\text { Continued neurological } \\
\text { improvement at } 3 \text { mos }\end{array}$ \\
\hline Gallia et al., 2005 & 21 days, $F$ & $\begin{array}{l}\text { Vomiting, irritability, } \\
\text { cranial nerve palsies }\end{array}$ & $\begin{array}{l}\text { Lt cavern- } \\
\text { ous ICA }\end{array}$ & $\begin{array}{l}\text { Lt middle } \\
\text { fossa mass }\end{array}$ & Coiled & $\begin{array}{l}\text { Unilat CN III, VI } \\
\text { palsies }\end{array}$ & $\begin{array}{l}\text { Resolving CN palsies at } \\
5 \text { mos }\end{array}$ \\
\hline $\begin{array}{l}\text { Huang et al., } \\
2005\end{array}$ & 30 days, $F^{*}$ & Cranial nerve palsies & $\begin{array}{l}\text { Lt cavern- } \\
\text { ous ICA }\end{array}$ & $\begin{array}{l}\text { Lt middle } \\
\text { fossa mass }\end{array}$ & Coiled & GOS Score 5 & Alive at $1 \mathrm{yr}$ \\
\hline $\begin{array}{l}\text { Wong \& Fong, } \\
2007\end{array}$ & 30 days, $\mathrm{M}^{*}$ & Seizures & Rt MCA & SAH, IPH & $\begin{array}{l}\text { Surgical exci- } \\
\text { sion }\end{array}$ & $\begin{array}{l}\text { No neurological } \\
\text { deficits }\end{array}$ & $15 \mathrm{mos}$ \\
\hline Sanai et al., 2006 & 58 days, $U^{*}$ & Hunt \& Hess 2 & Unspecified & $\mathrm{SAH}$ & Coiled & Good outcome & Alive at $1 \mathrm{yr}$ \\
\hline \multirow[t]{2}{*}{ Rana et al., 2007} & 31 days, $M$ & $\begin{array}{l}\text { Seizures, respiratory } \\
\text { depression }\end{array}$ & Rt MCA & $\mathrm{SDH}, \mathrm{IPH}$ & Coiled & $\begin{array}{l}\text { No neurological } \\
\text { deficits }\end{array}$ & $\begin{array}{l}\text { Developmentally normal } \\
\text { at } 15 \text { mos }\end{array}$ \\
\hline & 54 days, $F$ & $\begin{array}{l}\text { Seizures, irritability, rt } \\
\text { hemiparesis }\end{array}$ & Lt MCA & $\mathrm{IPH}$ & Coiled & Rt hemiparesis & $\begin{array}{l}\text { Dev delay, rt hemipare- } \\
\text { sis at } 3 \text { yrs }\end{array}$ \\
\hline $\begin{array}{l}\text { Van Raay et al., } \\
2009\end{array}$ & 7 days, $\mathrm{F}$ & $\begin{array}{l}\text { Fever, irritability, bulging } \\
\text { fontanelle }\end{array}$ & Rt PICA & IVH & $\begin{array}{l}\text { Clipped \& } \\
\quad \text { resected }\end{array}$ & $\begin{array}{l}\text { Swallowing dif- } \\
\text { ficulties }\end{array}$ & $\begin{array}{l}\text { Resolved swallowing dif- } \\
\text { ficulties at a few mos }\end{array}$ \\
\hline $\begin{array}{l}\text { González-Bonet } \\
\text { et al., } 2010\end{array}$ & 7 days, $F$ & $\begin{array}{l}\text { Hypotonia, decreased } \\
\text { level of consciousness }\end{array}$ & Lt MCA & IPH & Clipped & Rt arm paresis & $\begin{array}{l}\text { Rt hand paresis, normal } \\
\text { cognition at } 3 \text { yrs }\end{array}$ \\
\hline Choi \& Lee, 2013 & 28 days, $F$ & $\begin{array}{l}\text { Tense fontanelle, rt } \\
\text { hemiparesis }\end{array}$ & Lt MCA & SAH, IVH & Clipped & Rt hemiparesis & $\begin{array}{l}\text { Resolving hemiparesis } \\
\text { at } 3 \text { mos }\end{array}$ \\
\hline Fathi et al., 2015 & 60 days, $F^{*}$ & Seizures & Lt ACA & SAH, IVH & Clipped & $\begin{array}{l}\text { No neurological } \\
\text { deficits }\end{array}$ & $\begin{array}{l}\text { Delay in motor mile- } \\
\text { stones at } 2 \text { yrs }\end{array}$ \\
\hline $\begin{array}{l}\text { Del Santo \& Cor- } \\
\text { dina, } 2016\end{array}$ & 90 days, $F^{*}$ & $\begin{array}{l}\text { Limp, vomiting, down- } \\
\text { ward gaze }\end{array}$ & Rt SCA & $\mathrm{SAH}$ & Coiled & Good outcome & $\begin{array}{l}\text { Met all dev milestones at } \\
7 \text { mos }\end{array}$ \\
\hline
\end{tabular}


» CONTINUED FROM PAGE 361

TABLE 1. Previous reports of aneurysmal rupture in the first 3 months of life from saccular aneurysms, with aneurysm location, treatment, and outcome

\begin{tabular}{lrlcrcrc}
\hline Authors \& Year & Age, Sex & Presentation & $\begin{array}{c}\text { Aneurysm } \\
\text { Location }\end{array}$ & $\begin{array}{c}\text { Imaging } \\
\text { Findings }\end{array}$ & Treatment & $\begin{array}{c}\text { Outcome After } \\
\text { Intervention }\end{array}$ & Outpatient Follow-Up \\
\hline $\begin{array}{l}\text { Hidalgo et al., } \\
2017\end{array}$ & 26 days, F & Seizures, lethargy & Lt MCA & SAH, IPH, & Clipped & Good outcome & $\begin{array}{c}\text { Normal development at } \\
25 \text { mos }\end{array}$ \\
\hline Present case & 40 days, F & Limp, unresponsive & Rt MCA & SAH & Coiled & Seizures & Met all dev milestones at \\
& & & & & & 10 mos \\
\hline
\end{tabular}

$\mathrm{ACA}=$ anterior cerebral artery; $\mathrm{ACOA}=$ anterior communicating artery; $\mathrm{CN}=$ cranial nerve; dev = developmental; GOS = Glasgow Outcome Scale; ICA = internal carotid artery; IPH = intraparenchymal hemorrhage; IVH = intraventricular hemorrhage; $\mathrm{PICA}=$ posterior inferior cerebellar artery; SCA = superior cerebellar artery; SDH = subdural hematoma; $\mathrm{U}=$ unknown sex.

* Approximate age.

in infants less than 3 months old, we see an average followup of 12.5 months..$^{5,7,12,26,28,29}$ Although each case report has shown stable or improved patient outcomes at follow-up, the durability of a coil construct in an infant for more than 36 months is unknown. ${ }^{26}$ However, at least in adults, stable or improved angiographic results at the 6-month follow-up tend to predict an excellent long-term result. ${ }^{35}$

\section{Sequelae of Rupture}

Regardless of whether microsurgical clipping or endovascular coiling is used to treat a ruptured aneurysm in an infant, Proust et al. (2001) have suggested that the main determinant of outcome is the initial SAH itself. ${ }^{25}$ All patients with SAH are susceptible to delayed cerebral ischemia from vasospasm. In addition, the pediatric brain in particular is susceptible to developing other complications such as seizures if an area of the brain becomes injured. ${ }^{24,30}$ Our patient developed focal epilepsy, and the MRI study of the brain before treatment revealed a small right MCA distribution infarct (Fig. 1D). Subsequent electroencephalography confirmed the presence of epileptic activity arising from the right hemisphere.

\section{Conclusions}

Neonatal ruptured aneurysms are rare, and the exact cause is unknown. Currently, both endovascular and microsurgical treatments are valid options, each with special challenges. Until recently, microsurgical clip ligation was favored in the pediatric population of patients with aneurysms because of the technical challenges of angiography and embolization in neonates and a perceived reduced risk of recurrence compared with coil embolization. However, in a recent large-scale longitudinal study, Vanzin et al. (2012) showed that, at least in adults, if there is excellent occlusion by coil embolization at 6 months, then the chances of future recurrence are low. ${ }^{35}$ Nevertheless, in the neonatal age group it is hard to predict what might develop in the future, given the effects of maturation and a possible underlying genetic predisposition to aneurysm formation. Therefore, we recommend that MRA of the brain be performed every 6 months for the first 2 years after treatment, followed by yearly MRA of the brain. If an abnormal MR angiogram of the brain is obtained at any of these intervals, follow-up catheter angiography and possible retreat- ment should be performed. The durability of endovascular treatment will become clear as more centers report the long-term follow-up of these unusual patients.

\section{Acknowledgments}

We thank Dr. Patrick T. Noonan Jr. for helpful suggestions during the procedure.

\section{References}

1. Allison JW, Davis PC, Sato Y, James CA, Haque SS, Angtuaco EJC, et al: Intracranial aneurysms in infants and children. Pediatr Radiol 28:223-229, 1998

2. Buis DR, van Ouwerkerk WJR, Takahata H, Vandertop WP: Intracranial aneurysms in children under 1 year of age: a systematic review of the literature. Childs Nerv Syst 22:1395-1409, 2006

3. Caranci F, Briganti F, Cirillo L, Leonardi M, Muto M: Epidemiology and genetics of intracranial aneurysms. Eur $\mathbf{J}$ Radiol 82:1598-1605, 2013

4. Choi CY, Lee CH: Middle cerebral artery aneurysm in a premature neonate. J Korean Neurosurg Soc 53:371-373, 2013

5. Del Santo MA, Cordina SM: Infantile intracranial aneurysm of the superior cerebellar artery. J Neurointerv Surg 8:e50, 2016

6. Fathi NQ, Syahrilfazli AJ, Azizi AB, Redzuan IM, Sobri M, Kumar R: Ruptured giant left distal anterior cerebral artery aneurysm in a two-month-old baby. Pediatr Neurosurg 50:275-280, 2015

7. Gallia GL, Moore C, Jordan L, Gailloud P, Jallo GI: Neonatal cavernous carotid artery aneurysm: case report. J Neurosurg 102 (3 Suppl):332-337, 2005

8. González-Bonet LG, Ollero-Ortiz A, Giménez-Pando J, Márquez-Rivas J: [Neonatal intracranial haemorrhage secondary to spontaneous rupture of an aneurysm. Illustrative case and literature review.] Rev Neurol 50:403-408, 2010 (Span)

9. Grode ML, Saunders M, Carton CA: Subarachnoid hemorrhage secondary to ruptured aneurysms in infants. Report of two cases. J Neurosurg 49:898-902, 1978

10. Hidalgo J, Dickerson JC, Burnsed B, Luqman A, Shiflett JM: Middle cerebral artery aneurysm rupture in a neonate with interrupted aortic arch: case report. Childs Nerv Syst [epub ahead of print], 2017

11. Hosotani K, Tokuriki Y, Takebe Y, Kawaguchi K, Tsuji A, Kubota T: Ruptured aneurysm of the distal posterior inferior cerebellar artery in a neonate-case report. Neurol Med Chir (Tokyo) 35:892-895, 1995

12. Huang J, McGirt MJ, Gailloud P, Tamargo RJ: Intracranial 
aneurysms in the pediatric population: case series and literature review. Surg Neurol 63:424-433, 2005

13. Hungerford GD, Marzluff JM, Kempe LG, Powers JM: Cerebral arterial aneurysm in a neonate. Neuroradiology 21:107-110, 1981

14. Jansen FE, Vandertop WP, Velthuis BK: Aneurysm detection with computed tomographic angiography in a 1-month-old infant. Pediatr Neurol 23:361-363, 2000

15. Jones RK, Shearburn EW: Intracranial aneurysm in a fourweek-old infant. Diagnosis by angiography and successful operation. J Neurosurg 18:122-124, 1961

16. Kourtopoulos H, Lindgren S, Oberg L: Ruptured intracranial aneurysms in infancy. Diagnostic difficulties and overall reflections associated with the surgical treatment and the treatment of vasospasm. Acta Neurochir (Wien) 142:1425-1426, 2000

17. Kuchelmeister K, Schulz R, Bergmann M, Schwuchow R, Vollmer E: A probably familial saccular aneurysm of the anterior communicating artery in a neonate. Childs Nerv Syst 9:302-305, 1993

18. Lee YJ, Kandall SR, Ghali VS: Intracerebral arterial aneurysm in a newborn. Arch Neurol 35:171-172, 1978

19. Lipper S, Morgan D, Krigman MR, Staab EV: Congenital saccular aneurysm in a 19-day-old neonate: case report and review of the literature. Surg Neurol 10:161-165, 1978

20. Maroun F, Squarey K, Jacob J, Murray G, Cramer B, Barron $\mathrm{J}$, et al: Rupture of middle cerebral artery aneurysm in a neonate: case report and review of the literature. Surg Neurol 59:114-119, 2003

21. Newcomb AL, Munns GF: Rupture of aneurysm of the circle of Willis in the newborn. Pediatrics 3:769-772, 1949

22. Piatt JH Jr, Clunie DA: Intracranial arterial aneurysm due to birth trauma. Case report. J Neurosurg 77:799-803, 1992

23. Pickering LK, Hogan GR, Gilbert EF: Aneurysm of the posterior inferior cerebellar artery. Rupture in a newborn. Am J Dis Child 119:155-158, 1970

24. Pisani F, Pavlidis E, Facini C, La Morgia C, Fusco C, Cantalupo G: A 15 -year epileptogenic period after perinatal brain injury. Funct Neurol 32:49-53, 2017

25. Proust F, Toussaint P, Garniéri J, Hannequin D, Legars D, Houtteville JP, et al: Pediatric cerebral aneurysms. J Neurosurg 94:733-739, 2001

26. Rana AK, Koumellis P, Jaspan T, Cartmill M, McConachie NS: Coil embolization of ruptured middle cerebral artery aneurysms in the first 2 months of life. Report of two cases. $\mathbf{J}$ Neurosurg 107 (3 Suppl):232-235, 2007

27. Russegger L, Grunert V: A thrombosed giant MCA aneurysm in a ten-week-old infant. Neurochirurgia (Stuttg) 30:186-189, 1987

28. Sanai N, Quinones-Hinojosa A, Gupta NM, Perry V, Sun PP, Wilson CB, et al: Pediatric intracranial aneurysms: durability of treatment following microsurgical and endovascular management. J Neurosurg 104 (2 Suppl):82-89, 2006

29. Song JK, Niimi Y, Brisman JL, Fernandez PM, Berenstein A: Multiple cerebral aneurysms in a neonate: occlusion and rupture. J Neurosurg 102 (1 Suppl):81-85, 2005
30. Squier W, Salisbury H, Sisodiya S: Stroke in the developing brain and intractable epilepsy: effect of timing on hippocampal sclerosis. Dev Med Child Neurol 45:580-585, 2003

31. Stehbens WE: Pathology of the Cerebral Blood Vessels. St Louis: Mosby, 1972, pp 356-357

32. Tekkök IH, Ventureyra ECG: Spontaneous intracranial hemorrhage of structural origin during the first year of life. Childs Nerv Syst 13:154-165, 1997

33. Thrush AL, Marano GD: Infantile intracranial aneurysm: report of a case and review of the literature. AJNR Am J Neuroradiol 9:903-906, 1988

34. Van Raay Y, Darteyre S, Di Rocco F, Goodden J, Papouin M, Brunelle F, et al: Neonatal ruptured intracranial aneurysms: case report and literature review. Childs Nerv Syst 25:10251033, 2009

35. Vanzin JR, Mounayer C, Abud DG, D'Agostini Annes R, Moret J: Angiographic results in intracranial aneurysms treated with inert platinum coils. Interv Neuroradiol 18:391-400, 2012

36. Vapalahti PM, Schugk P, Tarkkanen L, af Björkesten G: Intracranial arterial aneurysm in a three-month-old infant. Case report. J Neurosurg 30:169-171, 1969

37. Vizcaíno-Díaz C, Sánchez-Zaplana H, Ruiz JC, Jiménez-Cobo B: Rupture of intracranial arterial aneurysms in neonates: case report and review of the literature. J Child Neurol 24:208-214, 2009

38. Wierdis T, Giannini V, Iaia E: Foetal and neonatal cerebrovascular disease. Early results of post-mortem carotid angiography. Panminerva Med 7:325-338, 1965

39. Wong ST, Fong D: Neonatal intracranial aneurysms: case report and review of the literature. Surg Pract 11:165-169, 2007

40. Young WF, Pattisapu JV: Ruptured cerebral aneurysm in a 39-day-old infant. Clin Neurol Neurosurg 102:140-143, 2000

\section{Disclosures}

The authors report no conflict of interest concerning the materials or methods used in this study or the findings specified in this paper.

\section{Author Contributions}

Conception and design: Lyon, Benardete. Acquisition of data: all authors. Analysis and interpretation of data: all authors. Drafting the article: Lyon, Arrey, Haider, Benardete. Critically revising the article: Lyon, Jeevan, Benardete. Reviewed submitted version of manuscript: Lyon, Jeevan, Benardete. Study supervision: Benardete.

\section{Correspondence}

Kristopher A. Lyon, Department of Neurosurgery, Scott and White Medical Center, 2401 S 31st St., Temple, TX 76508. email: kristopher.lyon@bswhealth.org. 